\title{
Job Stress among Faculty in Management Institutes
}

\author{
D. Raja Nandan ${ }^{1, *}$, K. Siva Rama Krishna ${ }^{2}$ \\ ${ }^{1}$ Department of Management Studies, Dr. L.B. College, India \\ ${ }^{2}$ GITAM Institute of Management, GITAM University, India
}

Copyright $\mathrm{O} 2016$ by authors, all rights reserved. Authors agree that this article remains permanently open access under the terms of the Creative Commons Attribution License 4.0 International License

\begin{abstract}
The present study aims at analyzing Job stress of faculty relating to management education in Andhra Pradesh State. Stress adversely impacts performance on the Job. The magnitude of Job stress differed across institutions with the highest score being in the AICTE (standalone) Institutes and declining in descending order among Deemed universities, Central universities, affiliated colleges, autonomous colleges and State Universities. Job stress exhibited variation by various factors.
\end{abstract}

Keywords Job Stress, Occupational Stress, Absenteeism and Turnover, Productivity, Management Education, Questionnaire, Social Support, Protective Factors

\section{Introduction}

Job Stress has been considered to be constraining organizational success. Satisfied employees work with more commitment and exhibit higher retention rates and higher productivity. Higher levels of job stress tend to lead to higher levels of absenteeism and declining mental and physical health. The data on job stress is useful in evaluating the emotional wellness and mental fitness of employees. Research on the factors causing stress could also help institutions of management to design suitable strategies to de-stress faculty from stress in order to assure and sustain quality in education. Job stress of faculty in management education institutions appears to be important as satisfied faculty are more committed and contribute quality inputs in teaching and research thereby enhancing the quality of student output. On the other hand, faculty under stress contributes negative inputs impacting in the reverse direction the quality of education. Hence, Job stress of faculty is crucial both to the students and the institution.

\section{Conceptual Analysis}

Job stress, also referred as occupational stress, organizational stress, job strain and work stress in the literature, is a concept that has been significantly researched in the past by Abdel-Halim [1]; Buunk, Doosje, Jans \& Hopstaken [2] and Cummins [3]. The literature clearly indicates that both physical and mental health is impacted by occupational stress. Specifically, research has shown that occupational stress has an impact on coronary heart disease as identified by Fitzgerald, Brown, Sonnega and Ewart [4]. Beehr, et. al. [5] found out that stress leads to emotional exhaustion, depression musculoskeletal disorder, diabetes, and cancer, which also is confirmed by Kristensen [6].

\section{Consequences of Stress}

Cooper and Marshall [7] identified that, in addition, an individual predisposed to occupational stress may develop psychological problems such as anxiety, depression, and nervousness. Behavioral problems, such as an increase in alcohol consumption and smoking, can also be seen among highly stressed employees according to Bacharach, et. al. [8]. According to La Rocco and Jones [9], occupational stress has also shown to reduce an individual's effectiveness and work performance. In addition, occupational stress has shown to negatively contribute to an individual's physical and/or psychological well-being according to Schirmer and Lopez [10]. For example, Wright [11] "estimated that 75-90 percent of all visits to primary care physicians are for stress-related problems".

Abdel-Halim [1] felt that the negative impact is of importance as it tends to cause negative effects not only on the employees but also on the overall productivity of an organization. The topic continues to be of increasing concern in today's society, since occupational stress has shown to be a leading cause of stress among individuals within the work setting as stressed by Wright [11]. The literature has also shown that occupational stress tends to contribute to an employee's high absenteeism and turnover rates according to Beehr, et. al. [12] and Cummins [3]. Furthermore, Wright [11] based on data collected from the U.S. Bureau of Labour Statistics showed that employees who are highly stressed or anxious tend to take more time off. Therefore, highly stressed individuals tend to have higher rates of absenteeism, 
which lead to lower rates of productivity for the organization. In addition to the higher rates of absenteeism, organizations have to pay more for employees' health care benefits as "econometric analyses show that health care expenditure increases nearly $50 \%$ for workers reporting high levels of stress" Wright [11]. This expenditure on health care provision results in approximately a $10 \%$ profit reduction for organizations as estimated by Manning, et.al. [13]. Thus, the ramifications of occupational stress are visible at both at the micro level (i.e., employees) and macro level (i.e., organizations). Earlier studies attempted to study Job stress at different levels considering specific factor(s). It is mostly applied to industrial context and rarely the case of educational institutions was studied.

\section{Objectives}

The present study is aimed at analyzing Job stress of faculty in management institutions in Andhra Pradesh with specific objectives as:

a) To identify factors impacting Job stress;

b) To analyze the relative influence of the factors impacting job stress; and

c) To suggest policy initiatives for the institutions to reduce/overcome stress among the faculty.

\section{The Sample}

The present study is confined to the faculty relating to management education in Andhra Pradesh State, which has the highest number of institutions offering MBA degree in India. Job stress of such a large number of faculty members is expected to have significant impact on the quality of output and thereby human capital, again affecting the sectors wherever they are employed. The sampling method used is as follows:

a) Among the universities, one Central university, and three state universities in the public sector (one in each of the regions of Andhra Pradesh) and two deemed to be universities in private sector offering MBA programme were selected.

b) Among the colleges affiliated to state universities-two autonomous colleges (one in Andhra and one in Telangana regions), four affiliated colleges (representing three regions) and two standalone AICTE institutions (one in Andhra and second in Telangana region) were selected as representative sample for the state of Andhra Pradesh.

c) All the population in each selected institution were taken and a predesigned questionnaire was canvassed to collect data on job satisfaction.

The type of institutions and the total population in each selected institution are presented in Table 1. A pre-designed questionnaire was canvassed among the faculty and data were collected during 2011-2012.

Several factors my influence Job stress and those factors that are quantifiable are considered for the analysis. The Stress is measured by using thirteen statements. Mean score is used to measure this variable.

Table 1. The Sample

\begin{tabular}{|c|c|c|c|c|c|c|}
\hline S. No. & Sector & $\begin{array}{c}\text { Type of } \\
\text { Institution }\end{array}$ & $\begin{array}{l}\text { Name of the } \\
\text { Institution }\end{array}$ & Place & $\begin{array}{c}\text { No. of Faculty } \\
\text { Members }\end{array}$ & $\begin{array}{c}\text { Year of Establish- } \\
\text { Ment }\end{array}$ \\
\hline & Government & Central University & $\begin{array}{c}\text { University of } \\
\text { Hyderabad }\end{array}$ & Hyderabad & 16 & 1970 \\
\hline & Government & State University & Andhra University & Visakhapatnam & 20 & 1926 \\
\hline & Government & State University & Osmania University & Hyderabad & 19 & 1916 \\
\hline & Government & State University & S.V. University & Tirupathi & 22 & 1954 \\
\hline & Private & Deemed University & GITAM University & Visakhapatnam & 49 & 1987 \\
\hline & Private & Deemed University & KL University & Vijayawada & 29 & 2007 \\
\hline & Private & Autonomous College & Gayatri & Visakhapatnam & 23 & 1980 \\
\hline & Private & Autonomous College & SIT & Hyderabad & 10 & 1998 \\
\hline & Private & Affiliated College & KMM & Tirupathi & 14 & 2003 \\
\hline & Private & Affiliated College & MRPG & Vizianagaram & 20 & 1987 \\
\hline & Private & Affiliated College & RIMS & Tirupathi & 27 & 1994 \\
\hline & Private & Affiliated College & ST. ANN'S & Hyderabad & 09 & 1983 \\
\hline & Private & AICTE Institute & BADRUKA & Hyderabad & 20 & 1950 \\
\hline & Private & AICTE Institute & IIAM & Visakhapatnam & 10 & 1987 \\
\hline \multicolumn{4}{|c|}{ Total } & & 288 & \\
\hline
\end{tabular}




\section{The Results}

It could be observed from Table. 2 that for the entire faculty in the present study stress is moderate with an average magnitude of 3.45 on a 5 point scale. Across the institutions by type, the range of variation is in between 3.36 and 3.51. Faculty in state universities appear to be relatively less stressed on one hand and faculty in deemed universities and standalone institutions recorded relatively more stress on the other hand. The results are on expected lines since teaching profession is always less stressed and hence the variation in stress across the institutions is marginal. Across the individual institutions (Table. 3) faculty in Andhra University experience the lowest stress relative to others followed by faculty in SV University in Tirupati, and SIT (one of the autonomous colleges). Faculty in IIAM (one of the standalone institution) and KMM College experienced maximum stress (3.58). Surprisingly, faculty in University of Hyderabad also recorded more than the average stress. Same is the case with faculty in KL University.
It may be relevant to examine as to what factors contribute to the stress experienced by the faculty. The causative factors vary across the institutions. It may be observed from Table. 2 that work environment, delay in sensitive issues, friends' advice and busy work significantly contribute to stress of the faculty in central university. In state universities, work stress, minding own business, work environment, sensitive issues and friends' advice are causing stress among the faculty. In case of deemed universities, everyday fatigue, work stress, minding own business, work environment and sensitive issues cause stress. In the case of autonomous colleges, everyday fatigue, sensitive issues, work environment, minding own business are more responsible for faculty stress. Same set of factors appear to be responsible for stress among faculty in the case of affiliated colleges. The sources of the stress in case of AICTE institutes are minding own business, work stress, everyday fatigue, sensitive issues, friends' advice in that order.

Table 2. Factors Affecting Stress by Type of Institution

\begin{tabular}{|c|c|c|c|c|c|c|c|c|}
\hline \multirow[b]{2}{*}{ Item } & \multirow[b]{2}{*}{ Statements } & \multicolumn{7}{|c|}{ Mean Scores } \\
\hline & & $\begin{array}{c}\text { Central } \\
\text { University }\end{array}$ & $\begin{array}{c}\text { State } \\
\text { Universities }\end{array}$ & $\begin{array}{c}\text { Deemed } \\
\text { Universities }\end{array}$ & $\begin{array}{c}\text { Autonomous } \\
\text { Colleges }\end{array}$ & $\begin{array}{l}\text { Affiliated } \\
\text { Colleges }\end{array}$ & $\begin{array}{c}\text { AICTE } \\
\text { Institutes }\end{array}$ & Total \\
\hline $\mathrm{A} 1$ & $\begin{array}{l}\text { hard-pressed for time } \\
\text { on job }\end{array}$ & 3.13 & 3.21 & 3.24 & 3.23 & 3.19 & 3.28 & 3.22 \\
\hline A2 & $\begin{array}{l}\text { I feel stressed at } \\
\text { work }\end{array}$ & 3.38 & 3.60 & 4.12 & 3.52 & 4.14 & 4.28 & 3.90 \\
\hline A3 & $\begin{array}{l}\text { I experience fatigue } \\
\text { everyday }\end{array}$ & 3.44 & 3.27 & 4.28 & 4.38 & 4.14 & 4.18 & 3.96 \\
\hline A4 & $\begin{array}{c}\text { I try to delay } \\
\text { sensitive issues }\end{array}$ & 4.00 & 3.92 & 3.86 & 4.04 & 3.97 & 3.98 & 3.95 \\
\hline A5 & $\begin{array}{l}\text { I wait for the right } \\
\text { moment to talk to my } \\
\text { HOD }\end{array}$ & 3.56 & 3.28 & 3.19 & 3.52 & 3.10 & 2.93 & 3.22 \\
\hline A6 & $\begin{array}{l}\text { I try to avoid snide } \\
\text { remarks at work }\end{array}$ & 3.69 & 2.51 & 2.44 & 2.76 & 2.41 & 2.33 & 2.56 \\
\hline A7 & $\begin{array}{l}\text { I assert myself when } \\
\text { I have to }\end{array}$ & 2.25 & 2.67 & 2.88 & 2.41 & 2.80 & 2.93 & 2.71 \\
\hline A8 & $\begin{array}{l}\text { I try to settle issues } \\
\text { by discussing them }\end{array}$ & 3.13 & 3.54 & 3.66 & 3.12 & 3.75 & 3.85 & 3.57 \\
\hline A9 & $\begin{array}{l}\text { I take the advice of } \\
\text { friends }\end{array}$ & 3.88 & 3.74 & 3.76 & 3.77 & 3.66 & 3.70 & 3.73 \\
\hline $\mathrm{A} 10$ & $\begin{array}{l}\text { I try to join the } \\
\text { general discussion of } \\
\text { the colleagues }\end{array}$ & 3.38 & 3.03 & 2.92 & 3.23 & 2.96 & 2.88 & 3.03 \\
\hline A11 & $\begin{array}{l}\text { I try to keep myself } \\
\text { busy at work }\end{array}$ & 3.69 & 3.19 & 3.47 & 2.80 & 3.27 & 3.45 & 3.27 \\
\hline A12 & $\begin{array}{l}\text { I mind my own } \\
\text { business }\end{array}$ & 3.50 & 3.93 & 4.12 & 3.67 & 4.14 & 4.30 & 4.00 \\
\hline A13 & $\begin{array}{l}\text { I cannot change the } \\
\text { work environment }\end{array}$ & 4.25 & 3.78 & 3.69 & 4.02 & 3.61 & 3.58 & 3.76 \\
\hline \multicolumn{2}{|r|}{ Aggregate Mean } & 3.48 & 3.36 & 3.51 & 3.42 & 3.47 & 3.51 & 3.45 \\
\hline
\end{tabular}


Table 3. Factors Causing Stress by Institution

\begin{tabular}{|c|c|c|c|c|c|c|c|c|c|c|c|c|c|c|c|c|}
\hline \multirow[b]{3}{*}{ Item } & \multirow[b]{3}{*}{ Statements } & \multicolumn{15}{|c|}{ Mean Scores } \\
\hline & & \multirow{2}{*}{$\frac{\mathbf{C U}}{\mathrm{UoH}}$} & \multicolumn{3}{|c|}{ State universities } & \multicolumn{2}{|c|}{$\begin{array}{c}\text { Deemed } \\
\text { University }\end{array}$} & \multicolumn{2}{|c|}{$\begin{array}{l}\text { Autonomous } \\
\text { Colleges }\end{array}$} & \multicolumn{4}{|c|}{ Affiliated Colleges } & \multicolumn{2}{|c|}{ AICTE Institutes } & \multirow[t]{2}{*}{ Total } \\
\hline & & & $\mathrm{AU}$ & OU & SVU & GU & KLU & GAY-ATRI & SIT & KMM & MRPG & RIMS & $\begin{array}{c}\text { ST. } \\
\text { ANNS }\end{array}$ & BAD-RUKA & IIAM & \\
\hline $\mathrm{A} 1$ & $\begin{array}{l}\text { Hard-pressed for } \\
\text { time to do job }\end{array}$ & 3.13 & 3.00 & 3.37 & 3.27 & 3.14 & 3.34 & 3.35 & 3.10 & 3.29 & 3.10 & 3.26 & 3.11 & 3.45 & 3.10 & 3.22 \\
\hline A2 & Stressed at work & 3.38 & 3.40 & 3.63 & 3.77 & 4.10 & 4.14 & 3.83 & 3.20 & 4.50 & 3.60 & 3.89 & 4.56 & 4.15 & 4.40 & 3.90 \\
\hline A3 & $\begin{array}{c}\text { Experiencing } \\
\text { fatigue everyday }\end{array}$ & 3.44 & 3.20 & 3.42 & 3.18 & 4.27 & 4.28 & 4.26 & 4.50 & 4.21 & 4.30 & 4.26 & 3.78 & 4.05 & 4.30 & 3.96 \\
\hline A4 & $\begin{array}{l}\text { Delay sensitive } \\
\text { issues }\end{array}$ & 4.00 & 3.75 & 4.00 & 4.00 & 3.86 & 3.86 & 3.87 & 4.20 & 3.86 & 4.05 & 3.85 & 4.11 & 3.95 & 4.00 & 3.95 \\
\hline A5 & $\begin{array}{l}\text { Wait for the right } \\
\text { moment to talk } \\
\text { to HOD }\end{array}$ & 3.56 & 3.05 & 3.47 & 3.32 & 3.20 & 3.17 & 3.43 & 3.60 & 3.00 & 3.40 & 3.33 & 2.67 & 3.05 & 2.80 & 3.22 \\
\hline A6 & $\begin{array}{c}\text { Try to avoid } \\
\text { snide remarks at } \\
\text { work }\end{array}$ & 3.69 & 2.35 & 2.68 & 2.50 & 2.49 & 2.38 & 2.52 & 3.00 & 2.43 & 2.60 & 2.48 & 2.11 & 2.25 & 2.40 & 2.56 \\
\hline A7 & $\begin{array}{l}\text { Assert myself } \\
\text { when I have to }\end{array}$ & 2.25 & 2.75 & 2.68 & 2.59 & 2.76 & 3.00 & 2.61 & 2.20 & 3.21 & 2.40 & 2.59 & 3.00 & 2.75 & 3.10 & 2.71 \\
\hline A8 & $\begin{array}{c}\text { Try to settle } \\
\text { issues by } \\
\text { discussing them }\end{array}$ & 3.13 & 3.80 & 3.32 & 3.50 & 3.63 & 3.69 & 3.43 & 2.80 & 3.93 & 3.35 & 3.48 & 4.22 & 3.80 & 3.90 & 3.57 \\
\hline A9 & $\begin{array}{c}\text { Take the advice } \\
\text { of friends }\end{array}$ & 3.88 & 3.55 & 3.95 & 3.73 & 3.69 & 3.83 & 3.74 & 3.80 & 3.71 & 3.80 & 3.70 & 3.44 & 3.60 & 3.80 & 3.73 \\
\hline $\mathrm{A} 10$ & $\begin{array}{l}\text { Try to join the } \\
\text { general } \\
\text { discussion of the } \\
\text { colleagues }\end{array}$ & 3.38 & 2.80 & 3.21 & 3.09 & 2.98 & 2.86 & 2.96 & 3.50 & 2.79 & 3.30 & 2.96 & 2.78 & 2.75 & 3.00 & 3.03 \\
\hline A11 & $\begin{array}{c}\text { Try to be busy at } \\
\text { work }\end{array}$ & 3.69 & 3.35 & 3.16 & 3.05 & 3.31 & 3.62 & 3.09 & 2.50 & 3.79 & 2.80 & 3.15 & 3.33 & 3.20 & 3.70 & 3.27 \\
\hline A12 & $\begin{array}{l}\text { Mind my own } \\
\text { business }\end{array}$ & 3.50 & 4.10 & 3.84 & 3.86 & 4.00 & 4.24 & 3.83 & 3.50 & 4.43 & 3.70 & 3.85 & 4.56 & 4.10 & 4.50 & 4.00 \\
\hline A13 & $\begin{array}{l}\text { Cannot change } \\
\text { the work } \\
\text { environment }\end{array}$ & 4.25 & 3.40 & 4.11 & 3.82 & 3.65 & 3.72 & 3.83 & 4.20 & 3.43 & 4.05 & 3.74 & 3.22 & 3.55 & 3.60 & 3.76 \\
\hline \multicolumn{2}{|c|}{ Aggregate Mean } & 3.48 & 3.27 & 3.45 & 3.36 & 3.47 & 3.55 & 3.44 & 3.39 & 3.58 & 3.42 & 3.43 & 3.45 & 3.43 & 3.58 & 3.45 \\
\hline
\end{tabular}


At the institutional level, work environment and minding own business consistently appear to be causing stress among faculty. These factors are followed by work stress, everyday fatigue, delay in sensitive issues, friends' advice causing stress. Hence, both work and non-work related factors appear to be responsible for stress among faculty across the institutions with only marginal variations in the magnitudes of the identified causative factors (Table. 3 ).

It is to be examined as to how the faculty are coping with the stress and what kind of strategies have they adopted. The information is provided in Tables. 4 and 5. It may be observed that social support in the form of visiting old friends and talking to friends on phone is the significant coping strategy to overcome stress by faculty across all the institutions. This is followed by playing games and watching TV. Surprisingly, relaxing doing nothing/sleeping is not a stress coping factor across all institutions. Also, surprisingly, religious work is not contributing to reducing stress of the faculty. The coping factors as observed from Table. 5 are similar even across individual institutions. Further, listening to music is also a stress coping factor in case of faculty working in Osmania University, SV University, KL University and Badruka College, Hyderabad.

Table 4. Factors Affecting Coping Strategies By Type of Institution

\begin{tabular}{|c|c|c|c|c|c|c|c|c|}
\hline \multirow[b]{2}{*}{ Item } & \multirow[b]{2}{*}{ Statements } & \multicolumn{7}{|c|}{ Mean Scores } \\
\hline & & $\begin{array}{c}\text { Central } \\
\text { University }\end{array}$ & $\begin{array}{c}\text { State } \\
\text { Universities }\end{array}$ & $\begin{array}{c}\text { Deemed } \\
\text { Universities }\end{array}$ & $\begin{array}{c}\text { Autonomous } \\
\text { Colleges }\end{array}$ & $\begin{array}{c}\text { Affiliated } \\
\text { Colleges }\end{array}$ & $\begin{array}{c}\text { AICTE } \\
\text { Institutes }\end{array}$ & Total \\
\hline A1 & Watch the TV & 3.31 & 3.25 & 3.26 & 3.24 & 3.22 & 3.30 & 3.25 \\
\hline $\mathrm{A} 2$ & $\begin{array}{c}\text { Meditate or do } \\
\text { Yoga }\end{array}$ & 3.06 & 3.31 & 3.78 & 3.15 & 3.37 & 3.40 & 3.37 \\
\hline $\mathrm{A} 3$ & $\begin{array}{l}\text { Play team } \\
\text { sports like } \\
\text { carroms, } \\
\text { shuttle, etc. }\end{array}$ & 3.63 & 3.85 & 3.97 & 3.50 & 3.97 & 4.13 & 3.88 \\
\hline A4 & Visit old friends & 4.06 & 4.14 & 4.25 & 4.09 & 4.14 & 4.25 & 4.16 \\
\hline A5 & $\begin{array}{l}\text { Talk to friends } \\
\text { on phone }\end{array}$ & 4.06 & 3.67 & 3.45 & 3.88 & 3.61 & 3.50 & 3.65 \\
\hline A6 & Listen to music & 3.31 & 3.26 & 3.28 & 3.33 & 3.28 & 3.38 & 3.30 \\
\hline A7 & Go to movies & 3.06 & 2.94 & 3.01 & 2.87 & 2.88 & 2.93 & 2.93 \\
\hline A8 & $\begin{array}{l}\text { Read a light } \\
\text { paperback }\end{array}$ & 2.88 & 3.06 & 3.13 & 2.90 & 3.14 & 3.28 & 3.09 \\
\hline A9 & $\begin{array}{l}\text { Work jigsaw } \\
\text { puzzles }\end{array}$ & 3.25 & 3.36 & 3.41 & 3.19 & 3.43 & 3.35 & 3.35 \\
\hline A 10 & $\begin{array}{l}\text { Relax doing } \\
\text { nothing or } \\
\text { sleeping }\end{array}$ & 3.31 & 2.95 & 2.86 & 3.25 & 2.80 & 2.68 & 2.92 \\
\hline A11 & $\begin{array}{l}\text { Involve in } \\
\text { gardening, } \\
\text { painting, } \\
\text { needlework, } \\
\text { etc. }\end{array}$ & 2.44 & 2.46 & 2.54 & 2.40 & 2.45 & 2.50 & 2.46 \\
\hline A 12 & $\begin{array}{l}\text { Attend to } \\
\text { religious work }\end{array}$ & 2.31 & 2.73 & 2.94 & 2.46 & 2.77 & 2.83 & 2.72 \\
\hline A13 & $\begin{array}{c}\text { Read serious } \\
\text { literature }\end{array}$ & 2.94 & 3.05 & 3.08 & 3.05 & 3.13 & 3.23 & 3.09 \\
\hline \multicolumn{2}{|c|}{ Aggregate Mean } & 3.20 & 3.23 & 3.31 & 3.18 & 3.25 & 3.29 & 3.24 \\
\hline
\end{tabular}


Table 5. Factors Affecting Coping Strategies By Institution

\begin{tabular}{|c|c|c|c|c|c|c|c|c|c|c|c|c|c|c|c|c|}
\hline \multirow[b]{3}{*}{ Item } & \multirow[b]{3}{*}{ Statements } & \multicolumn{15}{|c|}{ Mean Scores } \\
\hline & & \multirow{2}{*}{$\frac{\mathrm{CU}}{\mathrm{UoH}}$} & \multicolumn{3}{|c|}{ State universities } & \multicolumn{2}{|c|}{$\begin{array}{c}\text { Deemed } \\
\text { University }\end{array}$} & \multicolumn{2}{|c|}{ Autonomous Colleges } & \multicolumn{4}{|c|}{ Affiliated Colleges } & \multicolumn{2}{|c|}{ AICTE Institutes } & \multirow[t]{2}{*}{ Total } \\
\hline & & & $\mathbf{A U}$ & OU & SVU & GU & KLU & GAY-ATRI & SIT & KMM & MRPG & RIMS & $\begin{array}{c}\text { ST. } \\
\text { ANNS }\end{array}$ & $\begin{array}{l}\text { BAD- } \\
\text { RUKA }\end{array}$ & IIAM & \\
\hline $\mathrm{A} 1$ & Watch the TV & 3.31 & 3.15 & 3.37 & 3.23 & 3.24 & 3.28 & 3.17 & 3.29 & 3.19 & 3.25 & 3.19 & 3.11 & 3.20 & 3.40 & 3.25 \\
\hline $\mathrm{A} 2$ & $\begin{array}{c}\text { Meditate or do } \\
\text { Yoga }\end{array}$ & 3.06 & 3.20 & 3.42 & 3.32 & 4.07 & 3.48 & 3.30 & 3.50 & 3.26 & 3.37 & 3.26 & 3.56 & 3.40 & 3.40 & 3.37 \\
\hline $\mathrm{A} 3$ & $\begin{array}{l}\text { Play team sports } \\
\text { like carroms, } \\
\text { shuttle, etc. }\end{array}$ & 3.63 & 4.05 & 3.74 & 3.77 & 3.94 & 4.00 & 3.70 & 4.14 & 3.78 & 3.88 & 3.78 & 4.22 & 3.95 & 4.30 & 3.88 \\
\hline A4 & Visit old friends & 4.06 & 3.95 & 4.32 & 4.14 & 4.08 & 4.41 & 4.17 & 4.29 & 4.11 & 4.16 & 4.11 & 4.11 & 4.20 & 4.30 & 4.16 \\
\hline A5 & $\begin{array}{l}\text { Talk to friends } \\
\text { on phone }\end{array}$ & 4.06 & 3.55 & 3.68 & 3.77 & 3.59 & 3.31 & 3.65 & 3.21 & 3.67 & 3.65 & 3.67 & 3.56 & 3.60 & 3.40 & 3.65 \\
\hline A6 & Listen to music & 3.31 & 2.75 & 3.58 & 3.45 & 3.08 & 3.48 & 3.35 & 3.21 & 3.26 & 3.30 & 3.26 & 3.33 & 3.45 & 3.30 & 3.30 \\
\hline A7 & Go to movies & 3.06 & 2.95 & 3.05 & 2.82 & 2.98 & 3.03 & 2.83 & 3.00 & 2.85 & 2.93 & 2.85 & 2.67 & 2.65 & 3.20 & 2.93 \\
\hline A8 & $\begin{array}{l}\text { Read a light } \\
\text { paperback }\end{array}$ & 2.88 & 3.10 & 3.00 & 3.09 & 3.08 & 3.17 & 3.00 & 3.21 & 3.07 & 3.09 & 3.07 & 3.33 & 3.25 & 3.30 & 3.09 \\
\hline A9 & $\begin{array}{l}\text { Work jigsaw } \\
\text { puzzles }\end{array}$ & 3.25 & 3.75 & 3.11 & 3.23 & 3.51 & 3.31 & 3.17 & 3.50 & 3.30 & 3.35 & 3.30 & 3.56 & 3.10 & 3.60 & 3.35 \\
\hline A10 & $\begin{array}{c}\text { Relax doing } \\
\text { nothing or } \\
\text { sleeping }\end{array}$ & 3.31 & 2.60 & 3.21 & 3.05 & 2.86 & 2.86 & 3.00 & 2.64 & 2.96 & 2.92 & 2.96 & 2.44 & 2.65 & 2.70 & 2.92 \\
\hline A11 & $\begin{array}{l}\text { Involve in } \\
\text { gardening, } \\
\text { painting, } \\
\text { needlework, etc. }\end{array}$ & 2.44 & 2.50 & 2.53 & 2.36 & 2.53 & 2.55 & 2.30 & 2.64 & 2.37 & 2.46 & 2.37 & 2.33 & 2.20 & 2.80 & 2.46 \\
\hline A12 & $\begin{array}{l}\text { Attend to } \\
\text { religious work }\end{array}$ & 2.31 & 3.05 & 2.58 & 2.55 & 2.90 & 2.97 & 2.61 & 3.21 & 2.70 & 2.72 & 2.70 & 2.78 & 2.55 & 3.10 & 2.72 \\
\hline A13 & $\begin{array}{l}\text { Read serious } \\
\text { literature }\end{array}$ & 2.94 & 3.00 & 3.05 & 3.09 & 3.02 & 3.14 & 3.00 & 3.14 & 3.04 & 3.09 & 3.04 & 3.33 & 3.15 & 3.30 & 3.09 \\
\hline \multicolumn{2}{|c|}{ Aggregate Mean } & 3.20 & 3.20 & 3.28 & 3.22 & 3.30 & 3.31 & 3.17 & 3.31 & 3.20 & 3.24 & 3.20 & 3.26 & 3.18 & 3.39 & 3.24 \\
\hline
\end{tabular}




\section{Conclusions}

The results of this study indicated that both work-related and non-work related social support contribute more to the reduction of occupational stress. These results are consistent with an earlier study conducted by Fenlason and Beehr [14], who suggested that "work-related stress is most effectively dealt with by the work-related sources of support". However, work-related social support may be more beneficial in decreasing occupational stress than non-work-related social support due to the specific nature of the stress the individual is experiencing. Hence, support from colleagues may be more beneficial when the source of the stress the individual is experiencing is work-related.

Awareness of the different factors that may contribute to occupational stress is beneficial for organizations to consider in the implementation of preventive programmes, as "the effectiveness of coping strategies depends on different coping stages and stresses" Shen [15].

Occupational stress has shown to affect an individual not only physically but psychologically as well. However, protective factors such as social support and religious coping styles may help buffer occupational stress. Hence, with the implementation of proper protective factors these negative outcomes of occupational stress can be moderated.

Therefore, educational institutions may want to consider looking into preventative practices to assure that an individual's physical and psychological well-being is not being negatively affected by occupational stress. This proactive approach from an institution may help relieve some of the occupational stress that individuals are prone to experience. Therefore, with reduction of stress levels through the implementation of specific stress management interventions, institutions will be able to reduce the cost of health insurance among employees, as they become more attentive to the needs of their faculty.

One specific intervention that educational institutions may consider is the relationship between faculty and their superiors. The relationship between this dyad is an important one to investigate as studies have indicated that supervisory support tends to be a key contributor to decreasing occupational stress. Thus, targeting this specific relationship may help in reducing some of the adverse effects of occupational stress. Hence, proper supervisory training may be warranted to ensure that faculty obtains proper and effective support from their superiors.

\section{REFERENCES}

[1] Abdel-Halim, A. A. (1982). Social support and managerial affective response to job stress. Journal of Occupational Behavior, 3, 281-295. doi:10.102/job.4030030403.

[2] Buunk, B. P., Doosje, B. J., Jans, L. G. M., \& Hopstaken, L. E. M. (1993). Perceived reciprocity, social support, and stress at work: The role of exchange and communal orientation. Journal of Personality and Social Psychology, 65,801-811. doi: 10.1037.0022-3514.65.4.801.

[3] Cummins, R. C. (1989). Locus of control and social support: Clarifiers of the relationship between job stress and job satisfaction. Journal of Applied Social Psychology, 19, 772-788.doi:10.1111/j.15591816.1989.tb01258.x.doi:10.114 6/annurev.pu.15.050194.002121.

[4] Fitzgerald, S.T., Brown, K. M., Sonnega, J. R., \& Ewart, C.K. (2005). Early antecedents of adult work stress: Social-Emotional competence and anger in adolescence. Journal of Behavioral Medicine, 28, 223-230. doi: 10.1007/s10865-005-4658-x.

[5] Beehr, T. A., King, L.A., \& King, D.W. (1990). Social support and occupational stress: talking to supervisors. Journal of Vocational Behavior, 36, 61-61. Doi: 10.1016/0001-8791(90) 90015-T.

[6] Kristensen, T. S.(1996). Job stress and cardiovascular disease: A theoretical critical review. Journal of Occupational Health and Psychology, 1,246-260. doi:10.1037/1076-8998.1.3.246.

[7] Cooper, C.L., and Marshall, J. (1976). Occupational sources of stress: A review of the literature relating to coronary heart disease and mental ill health. Journal of Occupational Psychology (49, 11-28).

[8] Bacharach, S. B., Bamberger, P.A., \& Doveh, E. (2008). Firefighters, critical incidents, and drinking to cope: The adequacy of unit-level performance resources as a source of vulnerability and protection. Journal of Applied Psychology, 93,155-169. doi: 10.1037/0021-9010.93.1.155.

[9] La Rocco, J.M., \& Jones, A. P. (1978). Co-worker and leader support as moderators of stress-strain relationships in work situations. Journal of applied psychology, 63, 629-634. doi: 10.1037/0021-9010.63.5.629.

[10] Schirmer, L. L., \& Lopez, F.G. (2001). Probing the social support and work strain relationship among adult workers: Contributions of adult attachment orientations. Journal of Vocational Behavior, 59, 17-33. doi: 10.106/jvbe.2000.1777.

[11] Wright, J. (2007). Stress in the workplace: A coaching approach. Journal of Prevention Assessment \& Rehabilitation, $28,279-284$.

[12] Beehr, T. A., Jex, S. M., Stacy, B.A., \& Murray, M.A.(2000). Work stressors and coworker support as predictors of individual strain and job performance. Journal of Organizational Behavior, 21, 391-405. doi: 10.1002/(SICI) 1099-1379(200006) 21:4<391: AID-JOB15>3.0.CO;2-9

[13] Manning. M.R., Jackson, C.N., \& Fusilier, M.R. (1996). Occupational stress, social support and the costs of health care. Academy of Management Journal, 39, 738-750. doi: $10.2307 / 256662$.

[14] Fenlason. K. J., \& Beehr, T. A. (1994). Social support and occupational stress: Effects of talking to others. Journal of Organizational Behavior, 15,157-175.doi:10.1080/03069880 410001692201.

[15] Shen, Y.E. (2009). Relationship between self-efficacy, social support and stress coping strategies in Chinese primary and secondary school teachers. Stress and Health, 25, 129-138. doi:10.102/smi. 